\title{
EU Citizenship Needs a Stronger Social Dimension and Soft Duties
}

\author{
Maurizio Ferrera
}

\section{Introduction}

In the historical process of state formation, citizenship has played a key role for political integration. It has sorted out 'insiders' (the full members of the political community) from aliens/outsiders, has conferred to citizens an equal status, regardless of market and other social positions, it has stabilised and generalised compliance, sustained social cooperation, the legitimation of political authority and, last but not least, the formation of cultural and material bonds throughout the population.

With the Treaty of Maastricht, national citizenship has been complemented with a new layer, EU citizenship. It can be said that the purpose of this innovation was two-pronged: on the one hand, to rationalize (symbolically and institutionally) the disordered array of individual freedoms and faculties linked to the EU and its legal order; on the other hand, to create a new recognizable symbol capable of enhancing, precisely, political integration and mutual bonding among all EU citizens, regardless of nationality.

While there is evidence, twenty-five years on, that European citizens do know and value EU citizenship ${ }^{1}$, there is also some disappointment about the latter's actual effects in terms of integration and bonding, especially in the light of rising Euroscepticism, souverainisme and anti-immigration (including intra-EU mobility) sentiments.

In a recent speech, ${ }^{2}$ Rainer Bauböck has raised a challenging question: can the integrative functions of EU citizenship be enhanced and how? In a

This text has been written in the context of the REScEU Project (Reconciling Economic and Social Europe, www.resceu.eu), funded by the European Research Council (Advanced Grant no. 340534)

1 European Commission (2016), European Citizenship, Flash Eurobarometer 430/2016.

2 Bauböck, R. (2017), Still United in Diversity? The State of the Union Address, Florence, 5 May 2017, available at https://stateoftheunion.eui.eu/wp-content/ uploads/sites/8/2017/05/The-State-of-the-Union-Address-by-Rainer-Bauböck.pdf. 
nutshell, Bauböck's proposal is that we need to 'add stuff' in the container, in order to make it more immediately recognizable and salient to individual citizens and more effective as a bonding mechanism. Two additions are, in particular, proposed by this author: a stronger social component (individual rights and levels of protection that apply universally) and 'some duty'. EU citizenship is exclusively centered on rights: 'a duty-free citizenship does not support a sense of solidarity and it makes citizens less keen to hold governments accountable'.

I generally sympathize with this argument and welcome an open discussion on this topic. Before outlining an agenda for reform, we need, however, to better articulate the diagnosis and clearly identify the existing flaws of the EU citizenship construct - especially in its social dimension. With this aim in mind, I will start by briefly revisiting the key historical steps and elements of national and EU citizenship. I will then highlight the political shortcomings and perverse effects of the latter and single out the challenges that need to be addressed. The last sections will outline some modest proposals for 'adding stuff' to the EU citizenship container, making it more consequential and, hopefully, more capable of integrating and bonding.

\section{A bit of history}

Citizenship in the modern sense was born with the French Revolution. The Declaration of Human and Citizens' Rights (1789) identified a series of 'natural, sacred and inalienable' rights based on the fact that men are born free and equal. The 'political association' is tasked with defending and safeguarding these rights. Thus the citoyen is not only the bearer of natural rights, but also of state-backed guarantees for the exercise of such rights. During the nineteenth century, the pre-eminent political association became the nation (the nation-state). Membership of this entity began to be called nationality. With the advent of mass democracy and the welfare state, 'nationality' became the first filter for the exercise of the rights of citizenship and, prior to that, for the very legitimacy of a person's presence on the state territory. In the sense of 'nationality', citizenship assumed the role of 'assigning people to states', ${ }^{3}$ giving them the 'right to have rights' ${ }^{4}$ and participation in collective decisions.

3 Brubaker, R. (1992), Citizenship and Nationhood in France and Germany. Cambridge: Cambridge University Press.

4 According to Arendt's famous formula. See Arendt, H. (1951), The Origins of Totalitarianism. New York: Harcourt, Brace \& Co. 
Historically, the contents of citizenship/nationality appeared much earlier than the container. State formation was a slow process. For ordinary people, it essentially meant becoming subject to novel duties: paying taxes and serving in the army. Mass conscription was a key element of nationbuilding. It contributed to turning states into fully-fledged political communities, sharing an identity and a sense of 'destiny', with high symbolic charges as it implied the possibility of personal sacrifice. Territorial borders came to be perceived as 'inviolable' national boundaries to be defended usque ad effusionem sanguinis. Bounding promoted bonding, which in turn generalised and strengthened the affectual and normative loyalty vis-à-vis state authorities and their binding decisions. The link between taxation and nation-building was less strong. Up to World War I indirect taxes remained by far the most important source of state revenue. Personal income taxes were legally introduced between the end of the nineteenth and the beginning of the twentieth century but only acquired quantitative relevance in the second half of that century. The words for taxation used in Northern and Southern Europe testify that its impact on social solidarity and political legitimation varied greatly: think of the Scandinavian ska/skatt (which also means common treasury) vis-à-vis the neo-Latin terms impôt, imposta, impuesta (which evoke a subtraction).

The introduction of social entitlements as subjective rights greatly enhanced the material salience of citizenship. But it also imposed new duties. In 'Bismarckian' systems based on compulsory insurance, there was a programmatic link between contributions and benefits from the very beginning. In tax-funded, universalistic systems the link remained weaker. But in the UK, for example, the sense of civic duty and reciprocity was so strong that when the means-tested pension was introduced in 1908, elderly ladies in the countryside brought flowers and food to the post officers who once a week paid them a 'free' allowance.

During the Trente Glorieuses, the link between the duties and rights of citizenship (especially social rights) started to weaken. This phenomenon was noted as early as in 1950 by T.H. Marshall himself, who observed that in the UK citizenship was increasingly invoked for the defence of rights, ignoring 'the corresponding duties ... [which] do not require a man to sacrifice his individual liberty or to submit without question to the demands made by government. But they do require that his acts should be inspired by a

5 Harris, J. (1993), Private Lives, Public Spirit: A Social History of Britain 1870-1914. Oxford: Oxford University Press. 
lively sense of responsibility for the welfare of the community' ${ }^{6}$ Such sense of responsibility has been constantly eroding since the 1950 s, especially within the 'middle mass' of employees and pensioners. The growth of social spending has been accompanied by an increase of taxes and contributions. But since the 1990s survey evidence has shown that the vast majority of citizens think that they pay far too much for the benefits they receive - which they consider as untouchable entitlements and property rights. When the Italian trade unions supported the first reforms of a hugely unbalanced pension system in the early 1990 s, workers hurled iron bolts at their leaders: a striking departure from the times when old ladies brought flowers to the post office.

The welfare state has indeed been retrenched in the last couple of decades and the access to benefits and services has been made conditional or even 'contractual' (i.e. responsibility-sensitive) in the field of unemployment and social assistance. The big 'elephants' of the welfare state (pensions and health care) have also been reigned in, but the prevailing justificatory narrative has focused here on the need for cost containment, sustainability, or compliance with 'the demands of the EU'. The Marshallian 'lively sense of responsibility', the fact that the rights of citizenship cannot be severed from 'the corresponding duties' seem to have gone lost and appealing to them has today very limited political purchase. Even during economic crises or emergencies, consensus building must stay clear of duty-talk.

\section{Enter EU citizenship}

In his analysis of European citizenship, Paul Magnette has introduced the distinction between 'isopolitical' and 'sympolitical' rights (the distinction is drawn from the law and war practices of ancient Greece). ${ }^{7}$ Isopolitical rights are horizontal, as it were: they confer upon individuals belonging to a given political community the freedom to enter into the citizenship space of another community and enjoy the rights recognised by the latter. Sympolitical rights are 'vertical': they stem from a common authority which takes binding decisions for all the members of the participating communities - who in turn have some say on the content of such decisions.

National citizenship is predominantly sympolitical: its scope and content are decided by central authorities through democratic procedures. Only in

6 Marshall, T. H. \& T. Bottomore (1992), Citizenship and Social Class. London: Pluto, 41.

7 Magnette, P. (2005), Citizenship. The History of an Idea. Colchester: ECPR Press. 
the case of some welfare benefits are the national rights of citizenship isopolitical, e.g. when they allow any citizen to freely move and to enjoy whatever services - say health care - are provided at the local level, based on choices made by subnational authorities. In the historical federations, sympolitical social rights made a later appearance and still play a lesser role compared to unitary states: federated units have preserved substantial autonomy, especially in health care, social services and assistance. Here the federal government limits itself to guaranteeing free movement and nondiscrimination. ${ }^{8}$

What about EU citizenship? If we exclude some political rights (most notably the right to elect the European Parliament), EU citizenship is almost entirely isopolitical. It is derivative from national citizenship and basically entitles its holders to be treated as equals when they enter the citizenship space of another member state. The rights attached to the EU passport only apply when one crosses an internal border. True, the EU has adopted a Charter of Fundamental Rights and has recently launched a new initiative called the European Pillar of Social Rights. But these are rather soft rights, they apply only in respect of EU legislative acts and do not really add anything substantial to the catalogue of rights already existing in the member states.

EU citizenship does not confer subjective entitlements to material protections (transfers or services) directly provided by the EU. The limited supranational funds that exist in the social field (e.g. the European Social Fund) can only be accessed by national or regional governments. When sympolitical regulatory measures are adopted (e.g. on gender equality or employment protection) they need to be transposed into national legislation to become operative. Even if they concern individual cases, jurisdictional decisions - the rulings of the Court of Justice of the European Union (CJEU) - can only result from a request on the side of a national Court.

As all rights, also isopolitical ones have corresponding duties. In the first place, mobile citizens are subject to the same obligations that are in force in the country of destination: in particular, they must pay taxes and social security contributions. We can define these obligations as isopolitical duties. But 'isopolitics' generates a second, and less visible, type of duty. Stay-at-home citizens are obliged to make room for the mobiles, share with them their own national space (an identity-thick and rights-thick space) and bear the

8 Obinger, H., S. Leibfried \& F.G. Castles, (eds.) (2005), Federalism and the Welfare State: New World and European Experiences. Oxford: Oxford University Press. 
burdens of 'hospitality'.9 Empirical studies demonstrate that intra-EU mobility is not driven by benefit tourism and that, in the aggregate, it tends to benefit the receiving member states. But at the disaggregate level (this or that territorial area, this or that economic sector, this or that policy field) the negative economic and social externalities produced by the mobiles may be greater than the positive ones. The influx of citizens from other EU member states may in fact decrease - locally and contingently - the availability of scarce resources such as jobs, hospital beds, emergency care, social housing, school places and so on. ${ }^{10}$ While it may be true that national or local governments have not made the necessary public investments in this policy areas ${ }^{11}$, the fact remains that mobility has increased the overall problem pressure and originated novel unprecedented needs and policy challenges (e.g. in terms of educational assistance, spatial congestion and segregation, and so on). The social impact of mobility has been significant and it has been perceived as such by a great number of ordinary citizens, who 'blame Brussels' because mobility rules do come from Brussels.

Contrary to what happens at the domestic level, the social component of EU citizenship rests on regulation, not on allocation (i.e. material provisions directly funded through tax extractions on the side of the conferring authority). The obstacles to expand the EU budget and powers were (and still are) huge; when it was introduced - in the early 1970 s - social security coordination, instead of social supranationalisation, was probably the only feasible solution. But this strategy has caused serious political asymmetries: as a matter of fact, it has empowered a relatively small constituency of mobile citizens, at the (perceived) expenses of large majorities of non-mobile natives. ${ }^{12}$ In the medium and large EU countries, more than half of the natives have always lived in the region where they were born and hardly expect to exercise themselves the rights of free movement. On average, large majorities of nationals have never visited another EU country, watched $\mathrm{TV}$ or read a book in another language, used the internet to purchase goods from abroad. It is not surprising that many of these people perceive the

9 Ferrera, M. (2017), The contentious politics of hospitality. Intra-Eu mobility and social rights. European Law Journal, published online on 25 May 2017.

10 See European Commission (2014), Evaluation of the impact of the free movement of EU citizens at local level. Final Report. Brussels, January 2014.

11 As argued, among others, by the contributions in Part II of this book.

12 The capacity of free movement rights and actual transnational mobility to nurture a sense of identification with the EU seems to be, paradoxically, rather limited. See Damay, L. \& H. Mercenier (2016), 'Free Movement and EU Citizenship: a virtuous circle?' Journal of European Public Policy 23 (8): 1139-1157. 
rights of immigrants as a loss in the value of their own rights and opportunities within their communities. Such perceptions are stronger among the less educated and within poorer areas, where vulnerability is higher and immigration can be seen as a threat in the competition for scarce resources or as a symbolic threat to national values and identities. ${ }^{13}$ Free movement rights have expanded options (freedoms, faculties), but have also disturbed national social ligatures and thus tend to generate grievances which can beand have already been - easily politicised. The above-mentioned (cultural) transformation of social benefits and services into 'property rights' and the parallel erosion of the 'lively sense of collective responsibility' has offered, in turn, a fertile ground for the spread of resentments and feelings of relative deprivation.

As a result of these dynamics, the introduction of EU citizenship has not met its integrative and bonding promises. Quite to the contrary, it has provoked a sort of boomerang effect. The strategy of equal rights involves generating a 'we', but because of the isopolitical nature of the system, this strategy encounters the mobilisation of a different 'we'. As aptly put by Van Middelaar, the goal was 'Hurray, we Europeans can work in twenty-seven countries! The public response has in fact been: Polish plumbers are coming to take our jobs and Brussels is to blame! ${ }^{14}$

Is there a way to remedy this failure? If the diagnosis is correct, any remedial strategy must address two distinct challenges: 1) deactivating the current vicious disintegrative circle by rebalancing the isopolitical system; 2) making the rebalanced container of EU citizenship more visible and its content more substantial. Only after meeting these challenges can the question of attaching 'some duty' (as in Bauböck's proposal) be put on the agenda.

\section{Deactivating the vicious circle by empowering the stayers}

The rebalancing of the current isopolitical system can be achieved in two complementary ways: through a partial compensation for the negative externalities produced by free movers and through some forms of empowerment of those who do not exercise free movement rights. For the time being, it seems unrealistic to imagine that such responses can be given by creating

13 Ferrera, M., \& Pellegata, A. (2018 forthcoming). Worker mobility under attack? Explaining labour market chauvinism in the EU, Journal of European Public Policy.

14 Van Middelaar, L. (2013), The Passage to Europe. New Haven and London: Yale University Press, 261. 
individual sympolitical rights, i.e. subjective entitlements conferred directly by the EU on the basis of a joint decision and funded by EU taxation. But the EU can at least provide the resources for the necessary compensations. As mentioned, negative externalities are felt locally, for certain occupational groups and in respect of certain public and welfare services. The establishment of something like an EU Fund to ease the impact of mobility (or immigration more generally) could serve the purpose. It could work through national (better: subnational) applications and selection criteria based on adequate evidence of impact. In the UK a similar fund was established in 2008 by the Brown government and la ter (rather inconsiderately) scrapped by the Cameron government in 2010. According to a recent survey, the creation of such a pan-European scheme would be highly welcomed by EU citizens (see Figure 1).

Figure 1 Support for a common EU fund compensating national governments and local communities for the costs related to immigration

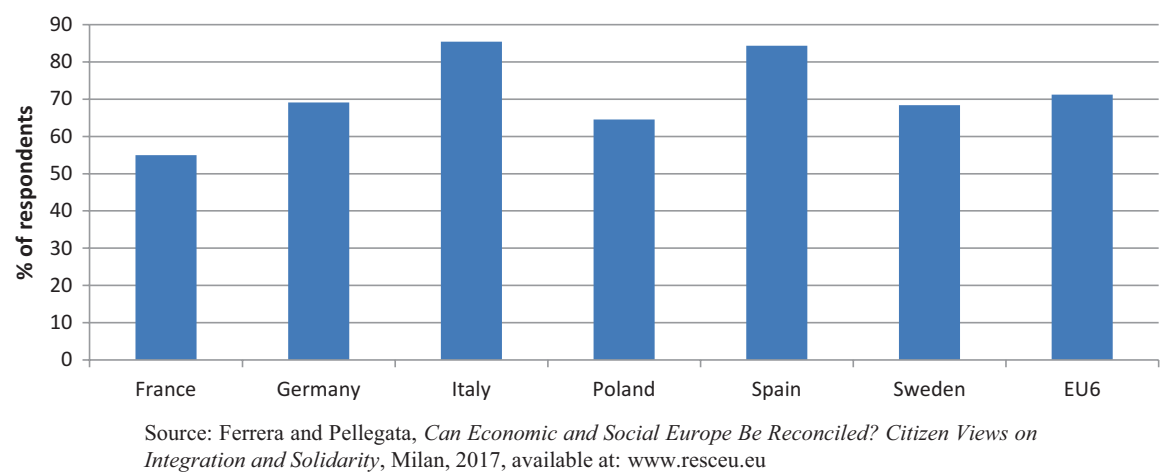

Empowering the stayers could be a second promising step. If we unpack isopolitical forms of protection, in addition to the binding supranational regulations that force the opening up of national spaces we also find a number of facilitating initiatives sponsored, organised and funded by the EU with a view to easing and supporting cross border mobility and transactions. Among these we can mention: information platforms such as EURES (European network of employment services), exchange programs such as Erasmus, the European health insurance card, e-health, quick assistance services to travelling citizens - including an EU-wide emergency number, 112 -, a support service for crime victims. A number of additional initiatives are planned for the future, such as a single digital gateway to receive counsel and assistance in cross-border situations or a common EU disability card. 
While it is true that all these facilitating initiatives provide tangible benefits only if there is a cross border element, their personal scope is potentially very wide: it goes well beyond the constituency of mobile workers, affecting travellers and tourists, patients, students, consumers. Among ordinary people there is only a very limited awareness of these initiatives. The first thing to do is thus to popularize these opportunities among the wider public, disconnecting them from free movement in the thick sense (i.e. work mobility).

A way of doing this would be to introduce an 'EU social card' (with a number identifier) available to all European citizens to enhance the visibility of (and also easing access to) the various privileges and services already provided by the existing programs. In the US the social security number is not only a pre-requisite for most contacts with the public administration, but also a visible and tangible symbol of membership in the US legal space. Italy has a similar code, which is called codice fiscale, requested for any application to a public benefit, in addition to being used for tax purposes. This number used to be shown on a dedicated plastic card, identifying each citizen (and legal resident) primarily as a taxpayer. Smartly, the number is now shown on a different card: the carta sanitaria - used to access the National Health Service -- which evokes the idea of an entitlement associated to tax duties. A clever move in terms of integration and bonding. ${ }^{15}$

A more ambitious idea is to create a direct stake also for stay-at-homers in the area of free movement. As has been aptly noted by various authors, the freedom to move implies also the freedom to stay. ${ }^{16}$ Those who opt for staying do not have access to the facilitating benefits and services that the EU provides to the movers. Why not imagine a scheme offering, upon application, universal transferable vouchers (or drawing rights) that workers could pass on to their kin - in particular sons and daughters wishing to move? Such vouchers (each having a certain value) could be used to access the existing benefits and services aimed for mobile workers or cashed in for covering extra expenses linked to mobility. Every worker would be entitled

15 One should not underestimate the symbolic - in addition to the practical and control-oriented - value of administrative papers in forging belongingness and even bonding. See the interesting historical reconstruction by Torpey, J. (2000), The Invention of Passports: Surveillance, Citizenship and the State. New York: Cambridge University Press. On the importance of symbols and everyday practices in EU building, see also the very interesting book by McNamara, K. (2015), The Politics of Everyday Europe. Oxford: Oxford University Press.

16 See the various responses to the kick-off essay by De Witte, supra, ft. 11. 
to a voucher. Some workers could just transfer their voucher to other workers or young people in search of job, wishing to move, thus endowing them with more value. One might also consider, however, to allow using vouchers for participating to lifelong learning activities at home (and/or in other member states, for short periods) on the side of workers who do not wish to exercise their right of long term free movement. One promising possibility would be to link the use of vouchers for temporary, short term participation to cross border training programs and exchanges. This system would increase the stakes of stay-at-homers. It is to be noted that EU facilitating schemes in the area of childcare, education, training, lifelong learning can be justified not only on the basis of free movement, but also on the mere fact of economic and monetary unification. Providing stayers with some EU funded benefit compensate them at least partially for the often disruptive impact of integration on domestic labour markets. ${ }^{17}$

\section{Making EU citizenship more visible and salient}

Personal security and welfare are today key political goods guaranteed by the liberal democratic nation-state. In what ways is EU citizenship complementing the security and welfare component of domestic citizenship? As is well known, Europe has no common army and only a very small (social) budget. It is hardly seen as a source of protection by its citizens. A relatively novel right (in part sympolitical, in part isopolitical) which has augmented the content of EU citizenship is the guarantee of consular protection abroad for EU citizens finding themselves in need of assistance in a country outside the EU where their home country is not represented. This novelty can be

17 This evolution might be seen as a social counterpart of an economic dynamic which affected in the past the free movement of goods and the competition regime. In the period which led to the completion to the single market, virtually all types of public regulations at the domestic level became subject to market-compatibility scrutiny regardless of the presence of cross border elements, in the wake of a maximalist interpretation of Treaty provisions (see. Poaires Maduro, M. (1999), 'Striking the Elusive Balance Between Economic and Social Rights in the EU', in P. Alston (ed.) The EU and Human Rights, 449-472. Oxford: Oxford University Press). The Lisbon Treaty could serve as the basis for a possible countermovement. European Monetary Union requires domestic adjustments which may clash with the social principles of the Treaty on European Union. Facilitating upskilling and lifelong learning at the national level even in the absence of cross-border elements could be defended based on the same logic that facilitated access to the market and deregulations at the domestic level, regardless of their pertinence for or link with free movement as such. 
interpreted as a branching out of EU citizenship from the internal to the external (i.e. extra-EU) sphere. According to some scholars, the external dimension remains today the only one in which citizenship continues to make a difference compared to mere legal residence. ${ }^{18}$ The external protection guaranteed by the Union to all its citizens as such would not only make the burgundy-coloured passport more consequential, but would also increase its symbolic value. As argued by Torpey, passport-based external protection can serve as an effective loyalty and bonding channel, for its capacity to 'embrace' movers as citizen-members of a political community. ${ }^{19}$ The Commission is currently studying a series of practical measures to make external protection of citizens more effective. A front along which this type of protection could be strengthened is the occurrence of terrorist attacks, in Europe and abroad. Italy already has a scheme for compensating (in the name of 'solidarity') the victims of terrorism and persons killed or injured in the line of duty. It might be a good idea to consider establishing a similar EU wide scheme, sending a signal of pan-European activism on a front - personal security - which is a fast growing popular concern.

The salience of EU citizenship could be enhanced also by strengthening the existing social funds and creating new ones. During the last decade two new funds have been created: the Globalisation Adjustment Fund, providing resources to workers affected by plant restructuring or closure, and the Fund for European Aid to Deprived Persons, providing resources in case of extreme poverty. Benefits are not paid directly to recipients, but through local authorities - which must previously apply for assistance. The indirect character and the small budget of these funds greatly limit their public visibility and salience. At a minimum, the EU should seek some credit by prescribing to local authorities to clearly indicate the provenance of resources at the endpoints of the delivery chain. If an "EU social card" was in place, it could provide a tangible instrument for linking benefits and EU citizenship.

In the wake of a proposal of the Italian government during its last EU presidency (following preparatory work by the Commission), the establishment of

18 Among others, Spiro, P. J. (2013), 'The (Dwindling) Rights and Obligations of Citizenship', William \& Mary Bill of Rights Journal 21: 899, Temple

University Legal Studies Research Paper No. 2013-46, available at http:// scholarship.law.wm.edu/wmborj/vol21/iss3/6; Bosniak, L.S. (1998), 'The Citizenship of Aliens', Social Text 56: 29-35,

19 Passports cannot be regarded merely as an instrument of government control. To use the words of the United States passport, the 'passport is a valuable citizenship and identity document'. See Torpey, cited above ft. 14 . 
an EU fund to compensate cyclical unemployment is currently on the EU agenda. This would be a major step in terms of pan-European solidarity - possibly one of the first important building blocks of a future European Social Union. Most likely, this fund will also operate indirectly. Given its wide personal scope, it will be extremely important to render the link between the EU and the resources accruing to national authorities and, ultimately, citizens as clear and evident as possible. Survey data show that popular support for panEuropean forms of solidarity (see Figure 2).

Figure 2 Support for various forms of pan-European solidarity (EU 6 averages)

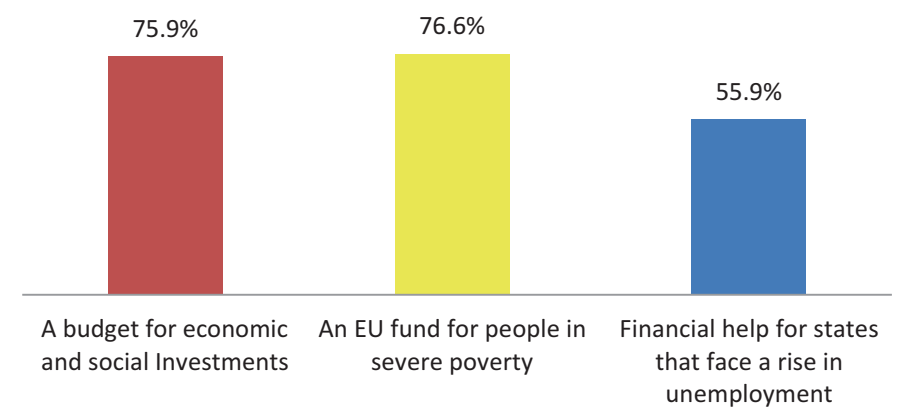

Source: Ferrera and Pellegata, Can Economic and Social Europe Be Reconciled? Citizen Views on Integration and Solidarity, Milan, 2017, available at: www.resceu.eu

Finally, a brand new supranational (and thus sympolitical) scheme could be established for insuring mobile workers against some risks (unemployment, maternity, disability etc.): a sort of 29th scheme (or 28th, after Brexit) separate from existing national schemes and providing homogeneous protections to those workers who move across borders. This idea has been circulating in the debate ever since the $1980 \mathrm{~s} .{ }^{20}$ As shown by Figure 3, popular support for the establishment of such a scheme would be very high. One of its advantages would be to ease the financial pressure (real or perceived) on domestic social protection systems stemming from the inflow of mobile workers and their families. In an ambitious scenario, this supranational scheme could catalyse the formation of cross-border insurance schemes, in line with the spatial and functional reconfiguration of the European econ-

20 Peters, D. \& S. Vansteenkiste (1992), The Thirteenth State. Leuven: Acco. 
Figure 3 Support for a common EU social insurance scheme that covers intra-EU migrant workers

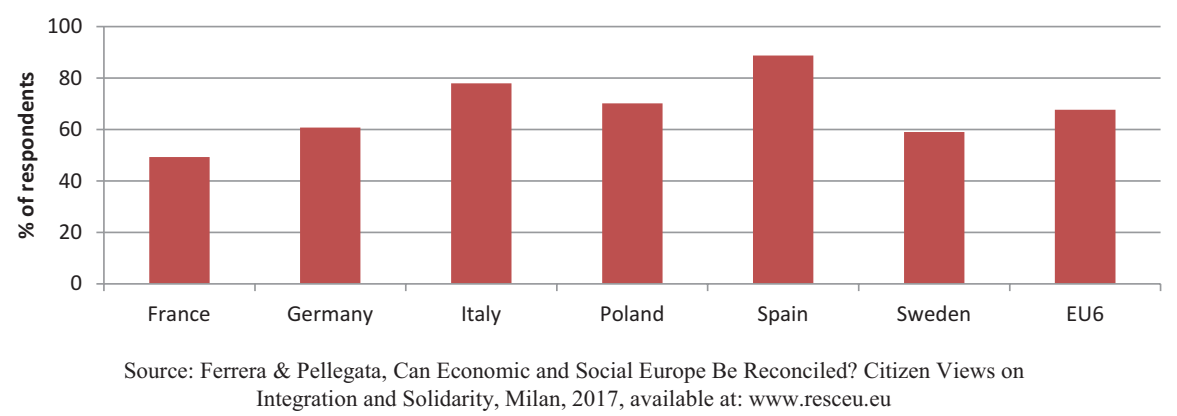

omy and labour market. In due course, such schemes might break the path towards novel forms of transnational risk pooling and thus solidarity. ${ }^{21}$

\section{Adding citizenship duties: Is it desirable? Is it feasible?}

The Lisbon Treaty makes it clear that EU citizenship is not 'duty-free': rights come with duties (art. 20 TFEU). So far, such duties essentially consist in complying with EU law, including free movement and its potential negative externalities. Would it be desirable to introduce some heavier, more tangible burden, directly linked to being a citizen of the Union?

As mentioned, the classical duties of citizenship (prior to it: of 'subjectship') have historically consisted in paying taxes and serving in the army. In present times, the former duty can be absolved through indirect taxation, income/wealth taxation, social security contributions and, to some extent, co-payments and fees-for-service. As to the latter duty, mandatory service is today the exception rather than the rule: the vast majority of EU countries have replaced it with voluntary service or with professional armies.

Given widespread anti-tax sentiments among voters, today the imposition of some explicit and visible EU tax would not be a good idea in terms

21 Cross-border pension schemes are already being experimented with in the wake of Directive 2003/41/EC. Almost 700,000 EU workers are already covered by such schemes. See: European Iinsurance and Occupational Pensions Authority (2017), 2016 Market development report on occupational pensions and cross-border IORPs. Frankfurt: EIOPA, available at https:/eiopa. europa.eu/Publications/Reports/EIOPA-BoS-16-222_2016\%20market $\% 20$ development $\% 20$ report $\% 202016$.pdf. 
of political support, integration and bonding. ${ }^{22}$ Even a recourse to 'the most Europeanised of all taxes', i.e. the VAT, could be counterproductive.$^{23}$ In the present context, the only feasible strategy would probably be to introduce some voluntary financial contribution 'for Europe' by means of nudging incentives. In some countries, when filling in their forms, taxpayers have the option to earmark a certain percentage (or per thousand) of their taxes for certain activities or institutions: churches, philanthropic, third sector, humanitarian institutions, political parties, cultural associations and so on. In Italy, 0.8 per cent is mandatory (taxpayers must choose between the state or a church among a list of different denominations); 0.5 per cent is voluntary (it can be earmarked for a long list of recognised institutions engaged in social, humanitarian and scientific research activities). An additional 0.2 per cent can be earmarked for political parties. The cinquexmille is chosen by more than 16 million taxpayers and produces an annual revenue of half a billion euros. A similar system could be established by all national tax authorities of the member states, giving the option of earmarking a small quota of personal taxes in favour of the EU as such (or, better still, of some of the abovementioned social funds). A bolder move of nudging would be to reverse the sequence of choice: the contribution for Europe (its social funds) is mandatory, unless the taxpayer explicitly opts out of it ('automatic enrolment').

Another possibility would be to use the co-payment or fee-for-service route in exchange for the array of facilitating initiatives that the EU already provides to ease the exercise of free movement and related rights. If access to the benefits and services of these initiatives (and the new ones that might be added) were filtered through an EU social card, the issuing (and renewal) of such card could be subject to a fee, to be used for funding the most expensive schemes (such as the above-mentioned voucher system). The UK scheme for easing the impact of migration was funded through a levy of 50 pounds on immigration permits. The possible fund for compensating the

22 Italy did introduce a tassa per l'Europa in 1997, to meet the deficit target required to join the euro. Nobody protested: but it was an extraordinary levy, for a defined goal, at the time perceived as beneficial for the whole nation. And then prime minister Romano Prodi promised that the tax would be paid back - a promise that was at least partially kept.

23 Van Parijs has proposed, for instance, an EU-wide VAT of 20 per cent to finance a monthly universal euro-dividend of 200 euros per month, for reference see Bidadanure, J. (2013), 'Rediscovering The Utopian In Europe: An Interview With Philippe Van Parijs', The Global Journal (26 March 2013), available at http://www.theglobaljournal.net/article/view/1038/. 
victims of terrorism could be financed through a small fee on the issuing of passports - obviously clarifying the purpose of this fee.

Beyond taxes and fees, another voluntary form of duty could be a panEuropean civil service for young people. The EU has recently established a European Voluntary Service and a European Solidarity Corps. Participating to such services could be made more appealing to young people by stressing the benefit of acquiring valuable skills and experiences. In due course, these two services could morph into some sort of an EU civilian defence and civic community service that could be chosen as an alternative to national service in those member states where the latter is mandatory; in the other member states it could still be chosen voluntarily. ${ }^{24}$ Although remaining far from proper and 'hard' duties, the proposed extractive instruments would indeed move in Bauböck's direction, through cautious and experimental steps. In the current 'euro-critical' context, jumping from 'duty-free' to 'duty-heavy' citizenship might be politically dangerous and even counterproductive.

\section{An incremental strategy - with a vision}

Following the tradition of Max Weber, we can define rights as sources of power (Machtquellen). Since power is a social relation in which somebody's 'will' causes the behaviour of somebody else, regardless of the latter's 'will', the creation of a right automatically creates a correlative duty of compliance. But what exactly are the power resources, which back the actual exercise of rights? First, there are normative resources: holding a right means having legitimate reasons to claim compliance (horizontally from fellow-citizens and vertically from political authorities). Secondly, there are enforcement resources: if compliance is not obtained, the right holder can activate legal coercion. Thirdly, there are instrumental resources: the conferring political authority typically provides the conditions for a full exercise of rights. In the case of social entitlements, for example, the state sets up social insurance systems (securing their financial bases), provides information and advice for accessing benefits and so on. While the second type of resources (enforcement) are what makes rights (and, by extension, citizenship) 'hard', in contemporary liberaldemocratic societies we should not underestimate the importance of the other two types: normative and instrumental resources.

24 The US National Guard and the Swiss militia system - originally meant for military and defence purposes - are being increasingly transformed into civilian defence and civic community services, and are often mobilised for various types of internal emergencies or natural disasters. 
Even when it adopts binding norms that indirectly impinge on national citizenship, the EU cannot provide enforcement resources directly to citizens. As mentioned, even access to the CJEU is mediated by national courts. The EU does provide, however, normative resources (if only through soft law) and EU citizenship does directly empower citizens with instrumental resources for the exercise of rights.

It is precisely the provision of instrumental resources (money, benefits and services, infrastructures and so on) that could make EU citizenship more salient, visible and tangible for wide social constituencies. A smart enhancement and packaging of such resources (accompanied by an adequate communication, capable of bringing some credit to the EU directly), could be the trampoline for strengthening the social citizenship dimension of the EU and experimenting with a range of soft duties. Intra-EU free movement rights (more precisely: the freedom to reside and work in any member state) is not only the hardest right of EU citizenship; it is also the only one that differentiates EU citizens from third-country legal residents. In other words, it is the key marker of EU belonging in the thick sense.

In the debate it is often argued that the increased harmonisation of rights and obligations between citizens and legal residents is making citizenship a less robust form of association, and that consequently its bonding potential has lost traction. The peculiar features of EU citizenship make it less sensitive, however, to such trends.

Internally, EU citizenship entitles to free movement. So far, this entitlement empowers only a limited constituency and has the risk of generating boomerang effects. In my scenario, the fact of free movement (and of the monetary union - a point which I cannot develop here) justifies the expansion of facilitating benefits and services that could be accessible to everybody: either in the form of transferrable drawing rights or in the form of access to training and life-long-learning services at home (or in another member state, for a short time) aimed at endowing all Europeans with the skills required by the new integrated European economy, based on a single market and international openness.

Externally, EU citizenship (which carries a passport eligibility foreclosed to third country legal residents) entitles to forms of protection against harms to personal or material security which are unfortunately becoming more frequent. The motto Civis Europaeus Sum would thus acquire a consequential meaning, both within and outside the EU. 


\section{Table 1 Enhancing EU social citizenship}

Compensating the stayers:

- $\quad$ EU Fund to ease the impact of mobility

Enabling the stayers:

A system of (transferable) universal vouchers for mobility/upskilling purposes Autonomising the movers:

- $\quad$ EU social insurance scheme for mobile workers

Universal empowerment and protection

A social card for access to the whole range of EU funded facilitating services

Enhancing the visibility and salience of the Global Adjustment Fund, the Fund for European Aid to the Most Deprived Persons (FEAD) and of the various initiatives of the European Social Fund

An EU Fund against cyclical unemployment

An EU insurance against the victims of terrorism and persons injured in the line of duty

Enhancing and making more visible the external protections linked to the EU passport

\section{Table 2 Possible forms of EU citizenship duties}

\begin{tabular}{l}
\hline $\begin{array}{l}\text { Financial duties: } \\
\text { An earmarked contribution for 'Social Europe' (or the European Social Union, or } \\
\text { any of the socially oriented EU funds) as a voluntary option when compiling } \\
\text { national tax forms (e.g. Italy's cinquepermille system) } \\
\text { Fees for the issuing/renewal of the EU social card and the EU passport (explicitly } \\
\text { earmarked for their 'protective' functions) } \\
\text { - } \\
\text { Personal duties: } \\
\text { An EU civilian defence and civic community service. As an alternative option for } \\
\text { young people of member states with mandatory services; as a voluntary option in the } \\
\text { other member states }\end{array}$
\end{tabular}

My proposals (summarised in Tables 1 and 2) may seem unambitious and low-key, but they have the advantage of being practical and can become operative without Treaty changes or major legislative innovations. National citizenship and welfare regimes were not born with a historical Bing Bang, but with a slow sequence of incremental reforms. Given the heavy legacy of 
such regimes, incrementalism is the only policy strategy for the EU today. A strategy that does not rule out the elaboration of grand political visions. Quite to the contrary, it presupposes visionary thinking, otherwise small steps become a purposeless and random walk, very likely to result in political failure.

Open Access This chapter is licensed under the terms of the Creative Commons Attribution 4.0 International License (http://creativecommons.org/licenses/by/4.0/), which permits use, sharing, adaptation, distribution and reproduction in any medium or format, as long as you give appropriate credit to the original author(s) and the source, provide a link to the Creative Commons license and indicate if changes were made.

The images or other third party material in this chapter are included in the chapter's Creative Commons license, unless indicated otherwise in a credit line to the material. If material is not included in the chapter's Creative Commons license and your intended use is not permitted by statutory regulation or exceeds the permitted use, you will need to obtain permission directly from the copyright holder. 